\title{
INTRODUCTION TO THE SPECIAL ISSUE
}

\section{GEORGE KIRAZ}

\author{
PISCATAWAY, NJ
}

[1] On the occasion of the 800th anniversary of the passing away of Mor Michael the Syrian (1126-1199), Patriarch of Antioch, a conference was hosted, between October 1-8, 1999, by the Syriac Orthodox Church at St. Ephrem Monastery in Maarat Saydnaya (outside of Damascus), the new Patriarchal seat and the headquarter of Church's main Seminary. The conference was convened by His Holiness Moran Mor Ignatius Zakka I, Patriarch of Antioch and All the East, and Mor Gregorios Yuhanna Ibrahim, Metropolitan of Aleppo. A report describing the conference was published in Hugoye 3,1.

In his inaugural address, H.H. the Patriarch welcomed scholars saying, "Hopefully, we will be able so soon to welcome scholars and orientalists in this monastery to benefit from our library and Syriac manuscripts, and enjoy communicating with Syriac speaking clergy and members of our Church." It is hoped that this conference will be a significant step towards more interactions between Western and Eastern scholars.

In the same speech, H.H. asked of scholars to view the history of the region from all angles. "I do implore respectful scholars and orientalists," he stated, "to attempt rewriting the history of this part of the world depending not only on western sources, but also on the historians from our Syrian Orthodox Church, like St. Michael, and not only on the history recorded by the victorious, but also on the history written by the defeated people."

We publish in this Special Issue of Hugoye selected papers from the conference. I wish to thank H.H. the Patriarch and 
Metropolitan Gregorios Ibrahim for giving Hugoye this opportunity. The entire proceedings are planned for publication, with an Arabic translation, by Metropolitan Gregorios Ibrahim. Other papers from the conference will be published in future issues of Hugoye. A paper by Susan Harvey titled "Theodora the 'Believing Queen:' A Study in Syriac Historiographical Tradition," which was presented at the said conference, will be published in the special issue on women. 